\title{
Endemik İçsu Balıkları Yetiştiriciliğinin Önemi: Eğirdir Sirazı (Capoeta pestai Pietschmann, 1933)
}

\section{Orhan DEMIR}

Süleyman Demirel Üniversitesi, Eğirdir Su Ürünleri Fakültesi, Su Ürünleri Yetiştiriciliği Bölümü, Isparta.

$\begin{array}{ll}\text { Geliş } & : 03.03 .2017 \\ \text { Kabul } & : 10.04 .2017\end{array}$

Sorumlu yazar: orhandemir@sdu.edu.tr

Derleme / Review

E-Dergi ISSN: $1308-7517$

Özet

Siraz balı̆ğ (Capoeta pestai Pietschmann, 1933), Eğirdir Gölü’nün endemik ayrıca ekonomik değeri yüksek bir Cyprinidae türüdür. Bu tür Eğirdir Gölü ile gölü besleyen akarsularda yayıllş̧ göstermesine karşın aşırı avcılık baskısıyla göldeki popülasyonu hızla azalmıştır. $\mathrm{Bu}$ problemin çözümü, doğal dengenin korunması, desteklenmesi, avcılık baskısının azaltılması, besin gereksinimlerinin karşılanması ile üretiminin yapılması ancak yetiştiricilik yöntemlerinin uygulanmasıyla mümkün olacaktır. Bunun en iyi kanıtı da, Türkiye'nin yetiştiricilik üretim miktarıyla toplam su ürünleri üretiminde geldiği seviyedir. Ayrıca yetiştiricilik üzerine çeşitli sektörlerce yapılan olumsuz propagandalara rağmen yetiştiriciliğin önemi de gün geçtikçe artmaktadır. Eğirdir Gölünden Şubat ayında avlanan ve boyları $20 \mathrm{~cm}$ üzerinde olan 4 dişi, 5 erkek siraz balığı ön çalışmada kullanılmıştır. Bunlardan $2^{+}-3^{+}$yaşlı dişi bireylerin ortalama standart boyu $24,60 \pm 0,82 \mathrm{~cm}$, ortalama canlı ağırlıkları 419,25 $46,40 \mathrm{~g}$ olarak hesaplanmıştır. Diseksiyonla bu bireylerin eşeysel olgunluğa ulaştığı ve ortalama ovaryum ağırlığının $35,9 \pm 1,9 \mathrm{~g}$, ortalama Gonado somatik indeks değeri (GSI) $0,0876 \pm 0,007$ ve ortalama yumurta verimleri $179000-250670$ adet $/ \mathrm{kg}$ arasında olduğu

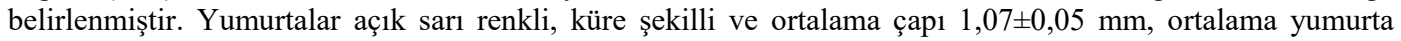
ağırlığ 1 ise $2,1 \pm 0,13 \mathrm{mg}$ olarak hesaplanmıştır. $3^{+}$ve $4^{+}$yaşlı erkek sirazların ortalama standart boyları $23,1 \pm 2,23 \mathrm{~cm}$, ortalama canlı ağırlıkları $253 \pm 46,16 \mathrm{~g}$, ortalama testis ağırlığ $5,36 \pm 2,23 \mathrm{~g}$ ve ortalama Gonado somatik indeks değeri (GSI) 0,02086 $\pm 0,0012$ olarak ölçülmüştür.

Anahtar kelimeler: Eğirdir Sirazı, Capoeta pestai, yetiştiricilik.

The Importance of Endemic Freshwater Fish Culture: Eğirdir Barb (Capoeta pestai Pietschmann, 1933)

\begin{abstract}
Eğirdir barb (Capoeta pestai Pietschmann 1933) is one of the endemic species of Cyprinidae family that is found in the Eğirdir Lake and it is economically important species. Although this species is distributed in the Eğirdir Lake and rivers feeding of this lake, in the ecosystem of the lake due to the excessive hunting pressure and the density of the population have been decreased rapidly. To solve this problem, protection of natural balance, support, reduction of hunting pressure, the supply of nutrient requirements and production can be done only through the application of aquaculture methods. Also, this is the best evidence that the amount of production of aquaculture in Turkey contributes most of the production of total fishery products. In addition, despite the negative propaganda of various sectors, the importance of aquaculture is increasing day by day. At the end of February, hunting than over $20 \mathrm{~cm}$ length of fish "Eğirdir barb" in Egirdir Lake, in 4 female and 5 male fish were used in the preliminary study. The mean standard length of $2^{+}-3^{+}$age old female fish is 24.60 $\pm 0.82 \mathrm{~cm}$ and the average body weight was calculated as $419.25 \pm 46.40 \mathrm{~g}$. Dissection of fish showed that fish reached sexual maturity and the weight of ovaries was measured to be as $35.9 \pm 1.9 \mathrm{~g}$, Gonad somatic index (GSI) of females were $0,0876 \pm 0,007$ and egg yields of females individual were estimated to be around 179 000-250 $670 \mathrm{eggs} \mathrm{kg}^{-1}$. The color of eggs were light yellow, spherical and the mean diameter of egg was measured $1.07 \pm 0.05 \mathrm{~mm}$ and the mean weight of egg was measured as $2.1 \pm 0.13 \mathrm{mg}$. Over $3^{+}$and $4^{+}$age males were $23.1 \pm 2.23 \mathrm{~cm}$ the mean standard length, $253 \pm 46.16 \mathrm{~g}$ the mean live weights. The mean testicles weights were measured as $5.36 \pm 2.23 \mathrm{~g}$ and GSI as $0.02086 \pm 0.0012$.
\end{abstract}

Keywords: Eğirdir barb, Capoeta pestai, aquaculture. 


\section{GİRIŞ}

Dünya nüfusunun 2050 yılında 9,6 milyara ulaşacağı, 2 milyardan fazla insanın açlık ve kötü beslenme sorunlarıyla karşı karşıya kalacağı bildirilmiştir (FAO, 2014). Dünyada kişi başı balık tüketimi ise 1960 yılında 9,9 kg, 1990 yılında 14,4 kg ve 2013'de yaklaşık 19,7 kg'a ulaşmıştır. Su ürünleri yetiştiriciliği yolu ile elde edilen üretiminin kişi başına düşen payı 1970 yılında 0,7 kg iken, 2008 yılında 7,8 kg ulaştığı belirtilmektedir (FAO, 2016). Bu bağlam da doğal kaynakların korunması ve sürdürülebilir kullanılmasına yönelik konular gelecek nesiller için önemli çalışma ve mücadele alanları olacaktır (FAO, 2014).

Tüm dünyada, başta Çin, Hindistan, Japonya, Endonezya, Filipinler ve Tayland olmak üzere birçok Avrupa ülkesinde Cyprinidae familyası üyeleri en yaygın ve yoğun kültürü yapılan türlerdir (FAO, 1985). Dünyanın en önemli su ürünleri yetiştiricisi olan Çin'de özellikle karnivor balıklara göre beslenme zinciri daha kısa olan sazan ve tilapia gibi omnivor ve herbivor türlerin kültürü yaygın olarak yapılmaktadır. Ayrıca bu türlerin yemlerinde daha düşük miktarlarda balık unu kullanılmasına rağmen, Çin'in yüksek üretim hacmi nedeniyle de önemli düzeyde balık unu tüketicisi olduğu da belirtilmektedir (Chiu vd., 2013).

Türkiye'nin su ürünleri üretiminde yetiştiriciliğin payı 1986 yılında 3075 ton, 2012 yılında 212410 ton olarak gerçekleşmiş (Demir, 2011, 2014), 2015 y1lında ise 240334 tona (toplam üretimin \% 35,7'si) ulaşmıştır. Bununla birlikte Türkiye'de toplam kapasitesi 479280 ton/y1l olan 2377 adet kayıtll su ürünleri yetiştiricilik tesisi olduğu bildirilmektedir (TÜIK, 2016). Ancak işletmelerin de \%50 kapasite ile çalıştıkları bu bilgilerden anlaşılmaktadır. Halbuki bu işletmelerin verimlilikleri \% 100 kapasiteye ulaşmış olsa, şu anki avcılık yolu ile elde edilen üretimden daha fazlasının olacağı görülmektedir.

Avcılık yolu ile iç su balıkları üretimi 2015 yılında 34176 tondur ve bunun \%21,1'ini de sazan balığı oluşturmaktadır. Bu verilerden sazan avcılığının 7223 ton olduğu (alabalık üretiminin yaklaşık 1/13-1/14) ve 2014 yılına göre de bu miktarın \% 10,1 azaldığ anlaşılmaktadır.

Güner vd. (2014), Türkiye'de mevcut imkanlar ve koşullar olumlu devam ettiğinde 2030 yılında toplam su ürünleri yetiştiriciliği miktarının 400000 tona ulaşmasını beklemekle birlikte 2016 yılının sonuna doğru da sazan yetiştiriciliğinin yok olma tehlikesiyle karşı karşıya kalacağı tahmininde bulunmuşlardır.

Türkiye'deki siraz türlerinin toplam üretiminin 2015 yllında 695 ton olduğu ve 2014 yılı verilerine göre de \% 1,6 azaldığı istatistiklerden anlaşılmaktadır (TÜiK, 2016). Eğirdir Sirazı'nın ilk kaydının Deveciyan (1915) tarafından yapıldığı belirtilmekle birlikte bilimsel olarak ilk tanımı Pietschmann (1933) tarafından yapıldığı anlaşılmaktadır. Pietschmann (1933)'nın çalışmasında populasyonda büyüklük farkından ortaya çıkan renk, beneklenme ve eşeysel farklılaşma nedeniyle Varicorhinus pestai ve Schizothorax prophylax olmak üzere iki tür şeklinde bildirilmiş olmasına karşın, türün bilimsel adının Capoeta pestai olduğu daha sonraki çalışmalarda açıklanmıştır (Küçük vd., 2009). Eğirdir'in yerel balıkçıları bu balıkların küçüklerini "Kelten" büyüklerini de "Şişek" olarak adlandırmıştır (Küçük vd., 2007). Eğirdir Sirazı'nın insan besini açısından ekonomik değeri olan ve 1980'li yıllardan önce yerel halk tarafindan taze olarak yoğun tüketilen, ayrıca salamura (kurma) balık olarak ta değerlendirilen bir tür olduğu bildirilmektedir (Geldiay ve Balık, 1996). 
Eğirdir Sirazı, 2009 yılına kadar olan bilimsel çalışmalarda Eğirdir Gölü ve Orta Anadolu tatlı sularında yayılış gösteren endemik bir tür şeklinde verilmiştir (Geldiay ve Balık, 1996; Küçük, 2006; Fricke vd., 2007). Ancak Beyşehir Gölü havzasında yaşayan siraz populasyonunu yeni tür $C$. mauricii (Beyşehir Sirazı) olarak tanımlanmıştır. C. pestai ve en yakın tür olan $C$. mauricii diğer Capoeta türlerinden farklı olarak, göl ortamına uyum sağlamış balıklardır (Küçük vd., 2009).

Konya ili sınırlarında bulunan Derebucak Çayından (Bakaran mevkisi) Haziran ayında yakalanan sirazların henüz yumurtalarını dökmediği (en azından bir kısmını), bu dönemde tam boyu 21,1 cm ve canlı ağırlığ1 102 g olan bir dişinin Gonado Somatik İndeks (\% GSI) değeri 11,56; ortalama yumurta çap1 1,36 $\pm 0,12 \mathrm{~mm}$, toplam yumurta sayıs1 7915 adet; fekondite değeri 77598 yumurta/kg canlı ağırlık olarak tespit edilmiştir. Aynı habitatta yakalanan üreme olgunluğundaki erkek bireyin toplam boyu 20,4 cm, canlı ağırlığ $79,8 \mathrm{~g}$ ve GSI değeri \% 2,47 olarak hesaplanmıştır. Ayrıca göl habitatlarında yaşayan türler daha erken (Mayıs-Haziran) üreme döngüsüne girerken, akarsu habitatlarında yaşayanlar çoğunlukla daha geç (Haziran-Temmuz) zamanlarda üremektedirler (Küçük ve Gülle, 2015).

Siraz, Eğirdir Gölü havzasında yaşayan diğer sazangillere göre soğuk ve 1lıman suları seven bir türdür (Küçük vd., 2009). Siraz balıkları vücudu uzun ve mekik şekilli, genellikle akarsuların hızlı akan, zemini taşlı ve kumlu kesimlerinde ve bol oksijenli ortamlarda yaşamalarına karşın, rakımı yüksek, suyu nispeten soğuk ve temiz göllerde de yaşamaktadırlar (Şekil 1). Durgun su habitatlarında yaşayanların üremek ve yumurtlamak üzere, özellikle ilkbahar ve yaz aylarında (Nisan-Temmuz döneminde) akarsu ağılarına giriş yaptığı, bol oksijenli ve akıntılı olan yukarı bölgelere doğru göç yaptığı belirtilmiştir (Küçük ve Gülle, 2015).

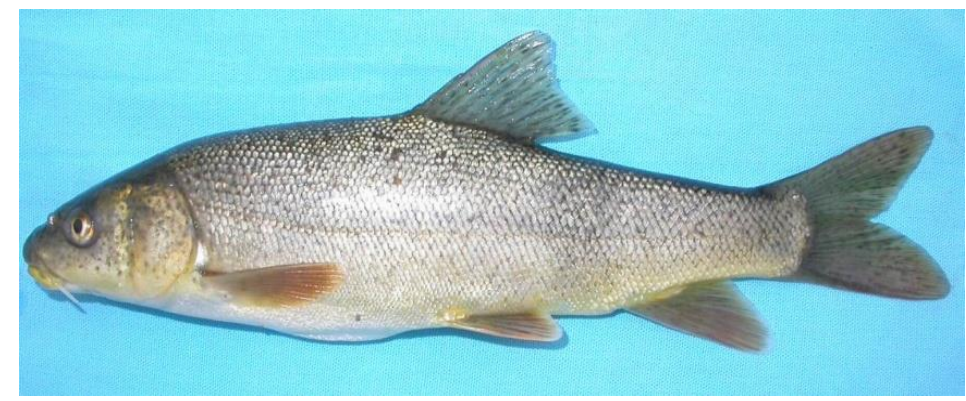

Şekil 1. Eğirdir Sirazı ( C.pestai) Çayköy Deresi, Eğirdir (Küçük vd., 2007)

Capoeta ekmekciae türünün alt çenesinin tipik keratin yapılı ve keskin olması nedeniyle kazıyıcı beslendikleri bildirilmektedir (Turan vd., 2006). Beslenmesi açısından çoğunlukla omnivor olan bu balıkların, oldukça uzun ve hassas bir sindirim kanalı bulunur. Siraz balıkları diğer sazangil formlarında olduğu gibi ortamın fiziksel özelliklerine, besin organizmalarının dağılımı ve bolluğuna bağlı olarak beslenme davranışlarını gelişim dönemlerine göre değiştirebilmektedirler (Küçük ve Gülle, 2015).

Yapılan araştırmalarda sirazın ötrofikasyona, çevre kirliliğine ve insan faaliyetlerine karş1 duyarlı, nadir, küresel önemi olan, yüksek koruma öncelikli, nesli hızla azalan ve tehlike altında olan bir tür olarak ifade edilmiştir. Ayrıca gölet-baraj yapı ve inşaatları, tarımsal sulama sistemlerinin su havzaları üzerine etkileri habitat kayıplarına neden 
olmakta ve siraz populasyonlarını tehdit etmektedir ( Fricke vd., 2007; Özcan ve Turan, 2009; David, vd., 2013).

Çeşitli antropojenik kirletici unsurların sucul organizmalar üzerinde yaptıkları etkiler biyolojik olarak izlenmiştir. Değişik zamanlarda yakalanan farklı büyüklük ve yaştaki sucul organizmaların dokularında, yaşam döngülerinde ve beslenme habitatlarında bu kirleticilerin varlıkları ve yaptıkları tahribatlar araştırmalarla tespit edilmiştir (Farkas vd., 2003).

Dağlı ve Erdemli (2011)'nin araştırmasında, Capoeta umbla numunelerinin toplam

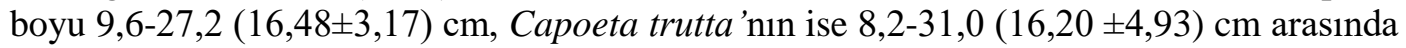
bulunduğu belirlenmiştir. Ayrıca bu çalışmada Fırat ve Dicle nehir sistemlerinde yaygın olarak bulunan ekonomik öneme sahip olan C. umbla ve C. trutta'nın kan parametreleri, toplam lipit ve yă̆ asidi bileşimi, serum proteinleri, karyotipi, avcılığ 1 , iç parazitleri, sindirim sistemi içeriği, hematolojik ve biyokimyasal parametreleri; C. umbla'nın yaş tayini ve boy ağırlık ilişkisi, büyüme özellikleri, üreme özellikleri, glikoz ve glikojen miktarı, kan parametreleri, popülasyon yapısı, total yağ ve yă̆ asitleri, ağır metal içeriği; C. trutta'nın yaş tayini, sindirim sistemi muhteviyat, total yağ ve yağ asitleri, iz element miktarı, büyüme özellikleri, et verimi ve kimyasal bileşimi, büyüme ve üreme özellikleri, hematolojik ve biyokimyasal parametreleri, ağır metal içeriği, serum testosteron, estradiol ve kolesterol miktarlarının çeşitli bilim insanları tarafından araştırıldı̆̆

Siraz gibi ekonomik önemi olan türlerin kültüre alınması ile sürdürülebilir yetiştiriciliğe, yem ve diğer yetiştiricilik uygulamalarına bağlı olarak ekosistem üzerindeki organik yük ve avcılık baskılarının en aza indirilmesine ve ekosistem tarafindan tolere edilebilir bir ölçekte olmasına, karnivor türlere göre besin zinciri daha kısa olan bu türün yetiştiriciliğinin yapılmasıyla da ekonomik, çevre dostu ve ekolojik bir üretime olanak sağlayacaktır.

Birçok ülkede olduğu gibi ülkemizde de sulak alanlar üzerinde yok edici aşırı avcılık baskıları ve bilinçsiz avcılık yöntemleri su ürünleri üretimini gün geçtikçe azaltmakta ve geri dönüşü olamayan noktaya getirmektedir. Bununla birlikte su ürünleri üretiminde, su ürünleri yetiştiriciliği konusu üzerine yapılan tüm olumsuz kara propagandalara rağmen yetiştiriciliğin önemi gün geçtikçe artmaktadır. Bu yargının yanlış olduğu yapılan çok sayıdaki araştırma ile ortaya konulmuştur. $\mathrm{Bu}$ çalışmalarla ekolojik dengenin korunmasının, doğal stokların desteklenmesi ve avcılık baskısının azaltılmasının, besin gereksinimlerinin karşılanmasının yetiştiricilik yoluyla olacağı da kanıtlanmıştır.

$\mathrm{Bu}$ bağlamda, ülkemizde sirazın yetiştiriciliğine ilişkin de yeterli düzeyde bilgi olmaması, aşağıda konu başlıkları belirtilen çalışmaların bir bilimsel disiplin içinde çalışılmasını gerektirmektedir. Bu konular;

Türün biyolojisi çalışmaları,

Hidrobiyolojik ve limnolojik çalışmalar,

Eğirdir siraz populasyonun durumu ve yetiştiricilik çalışmaları,

Biyotik ve abiyotik optimum çevresel isteklerinin belirlenmesi çalışmaları,

Anaç temini ve stoklama çalışmaları,

Yumurta eldesi ve inkübasyonu koşullarına ilişkin çalışmalar,

Erken larva dönemi yetiştiricilik ve besleme programı çalışmaları,

Bakım, besleme programı çalışmaları,

Hastalık teşhisi ve tedavi çalışmaları,

Genç ve ergin birey yetiştiricilik çalışmaları, 
Doğal stokların desteklenme programlarını oluşturma gibi daha birçok çalışmalar türün biyolojisine ekolojisi ve yetiştiriciliğine önemli katkıları sağlayacaktır.

\section{Hidrobiyolojik ve Limnolojik Çalışmalar}

Eğirdir Gölü, Türkiye'nin güney batısında, Isparta ilinde, $37^{\circ} 50^{\prime}-38^{\circ} 16^{\prime}$ kuzey enlemleri ile $30^{\circ} 57^{\prime}-30^{\circ} 44^{\prime}$ doğu boylamları arasında yer alan 2 . büyük tatlı su gölüdür. Antalya havzasında yer alan Eğirdir havzasının toplam büyüklüğü göl dahil $3020 \mathrm{~km}^{2}$ ve yüzey alanı $468 \mathrm{~km}^{2}$ dir. Deniz seviyesinden yüksekliği $917,7 \mathrm{~m}$, maksimum su hacmi 4 milyar $\mathrm{m}^{3}$ ve en derin yeri 13-14 m'dir (Şener vd., 2013; Beyhan ve Kaçıkoç, 2014). Eğirdir Gölü hidrodinamik model uygulamasında, göle giren ve gölden çıkan suyun akış hızı tanımlanırken göl ile bağlantısı olan Hoyran, Gelendost ve Aksu Deresi göle giren; Kovada Kanal1, Hoyran, Senirkent, Barla, Atabey, Boğazova ve Gelendost Sulaması ise gölden çıkan sular olarak tanımlanmıştır. Eğirdir Gölü suyunda sıcaklık tabakalaşmalarının olmadığı ve hidrodinamik model çalışmaları sonucunda, Eğirdir Gölü için, yeraltı suyunun bir rezervuar görevi yaptı̆̆ kanısına varılmıştır. Göle dışsal etkilerle taşınan fosfor ve azot miktarları ne kadar azalır ve hidrodinamik yapısı korunursa, su kalitesi açısından kendi kendini yenilemesi de o kadar kolay olacaktır (Anonim, 2013).

Eğirdir Gölü suyunun yıl boyu berrak ve kokusuz olduğu, tuzluluğun \%0,0, hidroksil ve karbondioksit parametrelerinin $0 \mathrm{mg} / \mathrm{L}$, bulanıklık 0,94-5,43 NTU (Eylül-Kasım), kondüktüvite 361,14-392,57 $\mu \mathrm{mhos} / \mathrm{cm}$ (Temmuz-Aralık), pH 6,94-8,66 (Ekim-May1s), sicaklık 4,64-24,71 ${ }^{\circ} \mathrm{C}$ (Aralık-Temmuz), çözünmüş oksijen 6,20-11,60 mg/L (EylülAralı), klorür 9,39-14,84 mg/L (Ağustos-Eylül), organik madde 14,50-20,85 mg/L (Kasım-Ağustos), bikarbonat; 194,67-218,96 mg/L (Aral1k-Ekim), karbonat 8,40-22,28 mg/L (Aralık-Eylül), sertlik 23,14-27,57 F (Ağustos-Kasım), kalsiyum 24,04-98,48 mg/L (Ağustos-Aralık), nitrat 0,51-1,33 mg/L (Temmuz-Eylül), amonyak 0,38-1,53 mg/L (Mayıs-Temmuz), sülfat 6,59-30,34 mg/L (Mayıs-Temmuz), fosfat 0,01-0,72 mg/L (Temmuz ve Mayıs-Mart), asit bağlama gücü 3,77-4,72 ml asit (Temmuz-Nisan) olarak bulunmuştur (Bulut vd., 2009).

Gölün kuzey bölümü sı̆̆ ve yer yer sazlık alanlarla kaplıdır. Eğirdir Gölü içme suyu, tarımsal sulama, balıkçılık, turizm ve enerji üretimi amaçlı kullanılmaktadır. Türkiye yüzey su kalite yönetmeliğine göre Eğirdir göl suyu kalitesinin nitrojen çeşitleri bakımından 1. sınıf olduğu, toplam fosfor bakımından ise 2. sınıf olduğu belirtilmiştir. Gölde ölçülen Chl-a değerleri makrofitlerden dolayı beklenen trofik durum indeksi (TSI) değerlerin daha düşük olarak saptanmıştır. Eğirdir gölünün bazı su kalite parametreleri sicaklik $15,15{ }^{\circ} \mathrm{C}\left(6,25-25,41^{\circ} \mathrm{C}\right), \mathrm{pH} 8,6(7,34-9,32)$, elektriksel iletkenlik $399,38 \mu \mathrm{s} / \mathrm{cm}$ (382-410,71 $\mu \mathrm{s} / \mathrm{cm})$, çözünmüş oksijen $8,98 \mathrm{mg} / \mathrm{L}(7,45-10,80 \mathrm{mg} / \mathrm{L})$, toplam azot 1,11 $\mathrm{mg} / \mathrm{L}(0,84-1,29 \mathrm{mg} / \mathrm{L})$, toplam fosfor $0,140(0,11-0,18 \mathrm{mg} / \mathrm{L})$, klorofil-a 2,14 $\mu \mathrm{g} / \mathrm{L}(0,65-$ $4,9 \mu \mathrm{g} / \mathrm{L}$ ) olarak ölçülmüştür (Beyhan ve Kaçıkoç, 2014).

Eğirdir Gölü'nün su sicaklığı 7,2-26,7 ${ }^{\circ} \mathrm{C}, \mathrm{pH}$ aralığı ise 7,58-8,54 arasında belirlenmiştir. Suda yapılan iyon analizleri sonucunda; nitrit ve fosfat hiçbir mevsimde tespit edilememiştir. Florür her mevsim bütün istasyonlarda ölçülürken, nitrat farklı mevsim ve istasyonlarda ölçülmüştür. Suda en fazla biriken anyonun florür olduğu görülmüştür. Sedimentte yapılan iyon analizlerinde ise; nitrit hiçbir mevsimde tespit edilememiştir. Nitrat ve florür her mevsim bütün istasyonlarda ölçülürken, fosfat farklı mevsim ve istasyonlarda ölçülmüştür. Sedimentte en fazla biriken anyonun nitrat olduğu görülmüştür. Eğirdir Gölü suyu çalışılan parametrelere göre I. kalite su sinıfında yer almaktadır (Kır vd., 2013). 
Eğirdir Gölü'nün Kovada kanalı bağlantı bölgesi klorofil a açısından oligotrof, toplam fosfor ve seki diski derinliğine göre mezotroftur. Eğirdir Gölü’nde ortalama toplam fosfor miktarı en düşük 0,10 (Ekim ayında), en yüksek 0,12 mg/1 (Temmuz ayında); klorofil a miktarı en yüksek Haziran ayında $(5,26 \mu \mathrm{g} / 1)$, en düşük Şubat ayında (1,07 $\mu \mathrm{g} / 1)$; ortalama seki diski derinliği ise 1,77 m (Aralık, Ocak)-2.07 m (Temmuz) olarak ölçülmüştür (Zeybek vd., 2012).

Eğirdir Gölü yağış, yüzey suyu ve yeraltı suyu akımı ile beslenmektedir. Gölün boşalım elemanları ise buharlaşma, sulama, içme suyu ve enerji amaçları için alınan sulardır. 1970-2010 periyodunda gölün gelir ve gideri arasındaki fark $7.78 \mathrm{hm}^{3}$ olarak hesaplanmıştır (Davraz vd., 2012).

Eğirdir Gölü'nün gelir-gider su bütçesinin tahmininde çeşitli analiz yöntemleriyle elde edilen bilgilere göre 100 yıllık süreçte \%24 oranında küçüleceği bildirilmektedir. $\mathrm{Bu}$ bağlamda, havzada yer altı suyu ve bitkisel üretimde kullanılan sulama suyunun azaltılması, etkili sulama sistemlerin yayınlaştırılması ve teşvik edilmesi, sürdürülebilir su kullanımı ile bütçe dengesinin kurulması gibi acil önlemlerin alınması gereklidir (Keskin vd., 2015).

Su- kayaç etkileşimi, evsel ve endüstriyel atıklar, tarımsal aktiviteler, yüzey madencilik faaliyetleri ve diğer birçok insan kaynaklı yapılar Eğirdir Göl'ü su kalitesini ve havzasını olumsuz etkilemektedir (Şener vd., 2013).

Kıyı ve sahillerin yönetimi, korunmasına ilişkin yeni bütünleşmiş düzenlemeler yapılmasında tüm paydaşların birlikte hareket etmeleri gerekliliği belirtilmiştir. Bu amaçla yapılacak yeni aktivite ve düzenlemeler üç alana ayrılmıştır. Bunlar;

1- Yasalarla çevreyi kullananların kullanım haklarının belirlenmesi (örneğin turizmci, balıkçı, sanayici vb. paydaşların faaliyetleri açısından),

2- Çevrenin biyolojik yapısı ve çeşitliğinin tüm ekosistemle birlikte korunması (biyoçeşitlik ve ekosistem havzalar bakımından),

3- Ekosistemin güvenliği ve fonksiyonlarının sürdürülebilirliği açısından besin, oksijen vb. sirkülasyonların sağlanması ve korunması konularıdır. Bunların dışında, insan kaynaklı aktiviteler ile birlikte yetiştiricilik faaliyetlerinin yaptığı etki ve baskıların sürdürülebilir yetiştiriciliği sınırladığı ifade edilmiştir. Ayrıca ekosistemler de bu durumlar dikkate alınarak üretim alanlarının taşıma kapasitelerinin bilimsel yöntemlerle belirlenmesi gerektiği de belirtilmiştir (Karakassis vd., 2013).

\section{Eğirdir Siraz Populasyonunun Durumu ve Yetiştiricilik Çalışmaları}

Ülkemizde ilk limnolojik çalışmaların yapıldığı bu gölde, sudak balığının aşılandığı 1955 yılına kadar 10 yerli balık türünün yaşadığı bildirilmiş olmasına karşın, 2009 yılında yapılan son taksonomik çalışmada Cyprinus carpio (Sazan), Vimba vimba (Eğrez), Capoeta pestai (Siraz), Pseudophoxinus egridiri (Ĕgirdir yă̆ balığı), Cobitis cf. turcica (Taş 1sıran), Seminemacheilus ispartensis (Çöpçü balığ1), Barbatula mediterraneus (Çöpçü balığı) ve Aphanius anatoliae (Dişli sazancık) olmak üzere 8 yerli balığın yaşadığı, sudak türünün predatör etkisi nedeniyle 1970 yılların başında gölün yerel endemiklerinden Pseudophoxinus handlirschi (Kavine, çiçek)'nin neslinin tükendiği (EX), Hemigrammocapoeta kemali (Ereğli otbalığı)'nın ise göldeki popülasyonunun yok olduğu bildirilmiştir. Ayrıca gölde Sudağın dışında 1996 yılında Carassius gibelio, 1998 yılında Knipowitschia caucasica, 2002 yılında Atherina boyeri görülmeye başlamış ve 2006 yılına gelindiğinde ise göldeki en baskın tür gümüş balığı olmuştur. Bu süre sonunda 
Eğirdir Gölü’ndeki ekonomik balık türlerinin (sazan ve sudak) avcılığında büyük bir düşme görülmüştür (Küçük vd., 2009).

Siraz balığı Eğirdir Gölü ile gölü besleyen akarsularda yayılış göstermesine karşın, bu türün aşırı avcılık ve predatör (sudak balı̆̆ı, Sander lucioperca (L.,1758)) baskısıyla 1970'li yılların başından itibaren göldeki popülasyonu hızla azalmış ve nesli tükenme düzeyine gelmiştir (Küçük vd., 2009).

Eğirdir Gölü üzerinde 2016 yılına kadar yapılan 249 adet araştırma makale başlıklarının verildiği çalışmada doğrudan Siraz populasyonunun durum ve yetiştiriciliği hakkında yeterli çalışma olmadığı görülmektedir (Yağcı ve Yağc1, 2016).

Sirazın yetiştiriciliğine ilişkin temel bilgilerin ve üretim tekniklerinin araştırılması ile yok olma tehlikesi sınırına gelen bu tür, varlığını sürdürülebilme olanağına sahip olmakla birlikte omnivor beslenme özelliği nedeniyle de ekolojik ve ekonomik açıdan da önemli bir türdür.

Sahada Şubat 2017'de yaptığımız ön çalışmada, standart boyları $20 \mathrm{~cm}$ üzerindeki 4 dişi, 5 erkek toplam 9 adet ergin siraz balığının cinsiyet, canlı ağırlık, standart boy, gonad ağırlıkları ve GSI değeri gibi bazı özellikleri ölçülmüştür. Eğirdir Siraz'ının $2^{+}-3^{+}$yaşlı dört dişi bireyin standart boy ortalaması $24,60 \pm 0,82 \mathrm{~cm}(23-30,5 \mathrm{~cm})$, canlı ağırlık

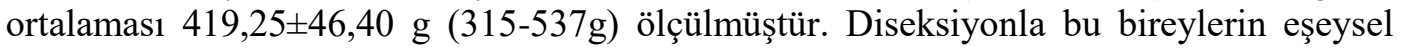

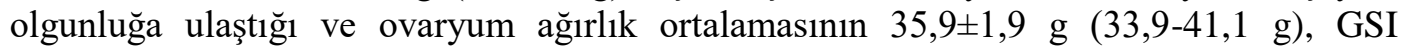
değerinin 0,0876 $\pm 0,007(\% 7,65-10,7)$ ve yumurta verimlerinin $179000-250670$ adet yumurta/kg olduğu hesaplanmıştır. Yumurtalar açık sarı renkli ve küre şekillidir. Ortalama çapı $1,07 \pm 0,05 \mathrm{~mm}(0,84-1,47 \mathrm{~mm})$ ve ortalama ağırlığı $2,1 \pm 0,13 \mathrm{mg}(1,84-$ $2.41 \mathrm{mg}$ )'dır. Erkek sirazlardan yaşları $3^{+}-4^{+}$üzeri olanların standart boy ortalaması 23,1 $\pm 2,23 \mathrm{~cm}(20,7-28 \mathrm{~cm})$, canlı ağırlık ortalaması $253 \pm 46,16 \mathrm{~g}(194-437 \mathrm{~g})$, testis ağırlık ortalamas $5,36 \pm 2,23 \mathrm{~g}(3.29-9.80 \mathrm{~g})$ ve GSI ortalama değeri de $0,02086 \pm 0,0012(\%$ 1,7-2,24) olarak hesaplanmıştır. Eğirdir siraz balığının erkek ve dişi bireylerine ait bu verilerin, Küçük ve Gülle (2015)'nin bildirdiği değerler ile önemli oranda örtüştüğü gözlenmiştir.

\section{Anaç Temini ve Stoklama Çalışmaları}

Doğal ortamlardan anaç temininde; türe özgü morfolojik özelikleri taşıyan sağlıklı erkek ve dişi bireylerden ağırlık, boy ve yaş bakımından uygun büyüklükteki damızlık adaylarının uygun zaman ve av araçları ile yeteri miktarda avlanması, uygun koşullarda stoklanması ve adaptasyonlarının gerçekleştirilme çalışmaları yetiştiricilik bakımından çok önemlidir. Çünkü yetiştiricilikteki başarı bireylerin/anaç adaylarının ortam koşullarına iyi uyum sağlamasına bağlıdır.

Doğadan temin edilecek damızlık bireylere ilişkin üreme özelliklerinin belirlenmesi yönelik gerekli ölçüm ve hesaplamaların yapılması gereklidir. Bunun dışında bu bireylerden üreme hücrelerinin elde edilmesi, döllenme işlemleri sırasında, ve sonrasında inkübasyon koşul ve yöntemlerinin belirlenmesi gibi çalışmalara ilişkin araştırmaların yapılması da canlı biyolojisi ve yetiştiriciliği açısından çok önemlidir.

Su ürünleri yumurta ve larva yetiştiriciliğinde başarıyı etkileyecek faktörleri üç başlıkta kısaca özetlenebilir. Bunlardan birincisi, anaç yönetimi, damızlık temini, kültüre alma, yumurtlatma (sağım), yumurtaların toplanması, inkübasyonu çalışmaları; ikincisi kuluçkahane içi ve dışı üretim alanlarında larva yetiştiriciliği çalışmaları; üçüncüsü de erken dönem larva besleme için canlı yem üretimi ve bu üretim tekniklerinin geliştirilmesi çalışmalarıdır. Bunların dışında larva yetiştiriciliğinde kanibalizim, su kalitesi ve salgın 
hastalıklar konusundaki sıkıntıların kitlesel ölümlere yol açtığı da araştırmalarla ortaya konulmuştur. Ancak, yetiştiricilikte yem ve yemleme programlarındaki bazı düzenlemelerle kanibalizimin önlendiği, kuluçka ortamlarındaki kapalı devre sistemlerinin kullanılmasıyla da su kalitesi ve salgın hastalıkların kontrol altına alındığı belirtilmiştir. Yetiştiricilik tesisi ve sistemlerinde, kullanılan suda, ayrıca döllenmiş yumurtaların dezenfeksiyonlarında ozon veya klor kullanımının olumlu etkilediği belirtilmektedir. Bunların yanı sıra larva yetiştiriciliğinde yeşil su kültürünün, kapalı devre sistemlerinin kullanılması ve ozonla dezenfeksiyon gibi birçok uygulamalarla larvaların keseli evreden tamamen karma yeme geçiş dönemine (weaning) kadar ki süreçte ölüm oranını binde seviyelerine düşürdüğü bildirilmiştir (Liao vd., 2001). Su ürünleri yetiştiriciliğinde, canlının üreme kapasitesi ve fonksiyonun kontrollü olarak denetimlerinin düzenli yapılmas1 sürdürebilir üreme ve üretimin temelini oluşturur. Bu bakımdan, doğal üreme mevsimi dışındaki dönemlerde fotoperiyot, su sıcaklığı vb. uygulamalar ile balıkların üreme fonksiyonları kontrollü olarak yönetilir (Constantinos vd., 2010).

\section{Yumurta Eldesi ve İnkübasyonu Koşullarına İlişkin Çalışmalar}

Jeuthe vd., (2013) balık yumurtalarının inkübasyonunda su sıcaklığının düşmesinin başarının azalmasına, bazı balık türlerinde uygun olmayan su sıcaklıklarının çene ve omurgada yapısal bozukluklarla birlikte ölümlere yol açtığını belirtmektedir. Ergin salmon türlerinde yüksek su sıcaklıklarının ovulasyonu engellediği veya ötelediği rapor edilmiştir. Yüksek su sıcaklığının fertilite oranının düşmesine ve inkübasyonu döneminde yumurtalarda ölüm oranın artmasına, ayrıca ilk defa yumurta verecek damızlık bireylerinde yaz mevsimindeki yüksek su sıcaklıklarına karşı çok duyarlı oldukları rapor edilmiştir.

\section{Erken Larva Dönemi Yetiştiricilik ve Besleme Programı Çalışmaları}

Kolkovski (2001)'e göre, balıkların prelarva evresinde sindirim sistemleri arasında çok önemli farklılıkların olmadığı, histolojik olarak bir tüp şeklinde olduğu belirtilmiştir. Ancak besin kesesinin tamamen çekilip ağzın açılması ile sindirim sisteminde farklılaşmaların başladığı bu dönemde de mide, mide bezleri ve plorik keselerin gelişimi tamamlanmaktadır. Karaciğer ve pankreas inkübasyon devresinde şekillenmiş ve ilk beslenme döneminde de fonksiyoneldir. İlk beslenme dönemlerinde larvaların sindirim sistemlerinin fonksiyonel olmadığı, midesiz balıklarda larvaların barsaklarında sindirim işlemleri ortam pH'sının alkali ve tiripsin benzeri enzimlerin proteolitik aktivitesinden söz edilmiştir. Barsak ve pankreatik enzim aktivitelerinin ilk beslenme dönemlerinde genellikle düşük düzeyde olduğu belirtilmiştir.

Japon balı̆ğ larvaları "farklı yemleme zamanı ve karma yem+canlı yem kombinasyonları" ile ilk 15 gün beslenmiştir. Larvaların canlı yemle beslenme süreçlerine ( 3,5 ve 7 gün) ve farklı yemleme zamanı programına göre gelişimleri ve yaşama oranlarının değiştiği ve canlı yemle besleme süresinin artışına koşut olarak arttı̆̆ belirtilmiştir. Buna göre ilk 7 gün canlı yem (tatlı su rotiferi), sonra 3 gün canlı yemle birlikte karma yemle, daha sonra da 5 gün süreyle tamamen kuru yemle beslenen grubun diğer tüm deneme gruplarına göre daha uygun besleme programı olduğunu bildirmişlerdir (Demir ve Sarıgöz, 2016). 


\section{Genç ve Ergin Birey Yetiştiricilik Çalışmaları - Doğal Stokların Desteklenme Programı}

Siraz balığ̣ yalnız Eğirdir Gölü'nde değil, aynı zamanda gölü besleyen akarsuların balıklandırılmasında da kullanılabilecek bir türdür. Türün kültürünün başarılmış olması durumunda ülkemizde nesli tükenme sınırında olan diğer türlerin yetiştiricilik yolu ile doğal stoklarının desteklenmesi konusunda da umut verici olacaktır.

\section{SONUÇ}

Diğer ülkelerde olduğu gibi, ülkemizde de yoğunlaşan av baskısı ve çevre kirliliği doğal kaynakların verimliliğini sınırlamaktadır. Avcılık yolu ile elde edilen ürün miktarının azalması, balık yetiştiriciliğini zorunlu kılmaktadır.

$\mathrm{Bu}$ derleme makalesinde belirtilen kaynak ve istatistiksel veriler 1ş1ğında ülkemizde herbivor ve omnivor balıkların yetiştiriciliğine çok önem verilmediği ortaya konulmuştur. Bununla birlikte ülkemizdeki yerel popülasyonların biyo-ekolojisi, populasyon dinamiği, sistematikleri ve fizyolojileri üzerine çok sayıda çalışmalar olmasına karşın, türlerin yetiştiriciliğine ilişkin sınırlı sayıda olduğu anlaşılmaktadır. Ülkemizde yetiştiricilik açısından sazan balığı en önemli tür olmakla birlikte alternatif bir tür olarak da siraz balığının ele alınmasının gerekli olduğu kanısındayım. Bu durum hem yetiştiricilik hem de doğal stokların takviyesi açısından da önemlidir.

Deniz ve iç sularımızdan avcılık yoluyla elde edilen su ürünleri üretiminin sürekli dalgalandığ1 ve zaman zaman düştüğü, devamlı artan nüfusumuza bağlı olarak kişi başına düşen balık tüketiminde istenilen düzeye ulaşmadığı açıktır. Ayrıca içme suyu kalitesindeki iç sularımızda sürekli karnivor türlerin üretiminin gündemde oluşu, gelecekte toplumuzun temiz su gereksinimini de zora sokacağ 1 gerçeği göz ardı edilmemelidir. Bu gerçekler doğrultusunda sazan ve siraz gibi ekonomik değeri olan herbivor ve omnivor türlerin yetiştiriciliğini mutlak olarak destekleyen politikalar geliştirilmeli ve uygulanmalidir.

İç su kaynaklarında siraz gibi ekonomik önemi olan türlerin kültüre alınması ile sürdürülebilir yetiştiriciliğe, yem ve diğer yetiştiricilik uygulamalarına bağlı olarak ekosistem üzerindeki organik-inorganik yüklerin, baskıların en aza indirilmesine dolayısıyla ekonomik, çevre dostu ve ekolojik bir üretime olanak sağlayacaktır.

Birçok ülkede olduğu gibi ülkemizde de sulak alanlar üzerindeki geri dönüşü olmayan yok edici aşırı avcılık baskıları nedeniyle su ürünleri üretimi gün geçtikçe azalmaktadır. Günümüzde ve gelecekte insanların çeşitli istemlerinin, gereksinimlerinin karşılanmasında, ekolojik dengenin korunmasında ve doğal stokların desteklenmesinin de her şeye rağmen yetiştiricilik yoluyla olacağı çok sayıda araştırma ile ortaya konulmuştur. Ayrıca su ürünleri yetiştiriciliğinin önemi de gün geçtikçe artmaktadır.

$\mathrm{Bu}$ bağlamda, ülkemizde sirazın yetiştiriciliğine ilişkin araştırmaların sayıları arttırılmalı, bu konudaki bilgi açığı kapatılarak türün yetiştiriciliğine ilişkin bölgesel ve ulusal ölçekte gerekli önem ve değer verilmelidir.

\section{KAYNAKLAR}

Anonim, (2013). Eğirdir Gölü'nde kirlilik durumu ve kirlilik kaynakları modelleme çalışması raporu. Yedi Renkli Göle Yedi renkli Hayat Projesi, WWF, 36s.

Beyhan, M., \& Meltem, K. (2014). Evaluation of Water quality from the perspective of eutrophication in Lake Eğirdir, Turkey. Page 2 of 13 Water Air Soil Pollut, 225,1994. 
Bulut, C., Atay, R., \& Uysal, K. (2009). Eğirdir Gölü’nde fiziko-kimyasal parametrelerin mevsimsel değişimi ve limnolojik açıdan değerlendirilmesi. Anadolu Üniversitesi Bilim ve Teknoloji Dergisi A - Uygulamalı Bilimler ve Mühendislik 10(2).

Constantinos, C., Fostier, M. A. \& Zanuy, S. (2010). Broodstock management and hormonal manipulations of fish reproduction. General and Comparative Endocrinology 16,5 516-534.

Chiu, A., Li, L., Guo, S., Bai, Fedor, J., \& Naylor, R. L. (2013). Feed and fishmeal use in the production of carp and tilapia in China. Aquaculture 414(415), 127-134.

Dağlı, M., \& Erdemli, A. Ü. (2011). Capoeta umbla (Heckel, 1843) ve Capoeta trutta (Heckel, 1843)'nın bazı meristik ve morfometrik özelliklerinin karşıllaştırılması. The Black Sea Journal of Science Symposium Special Issues 2(5), 46-56.

David, L., Noakes, G., \& Lynn, D.B. (2013). Threatened fishes of the world: the end of a series. Environ. Biol. Fish. 96, 1135-1149.

Davraz, A., Şener, E., Şener, Ş., \& Varol, S. (2012). Water balance of Eğirdir Lake and the influence of budget componenets, Isparta, Turkey. International Earth Science Colloquium on the Aegean Region, Proceedings Book, p. 183, 2012-10-01, İzmir

Demir, O. (2011). Türkiye su ürünleri yetiştiriciliği ve yem sektörüne genel bakış-II. SDU. Eğirdir Su Ürünleri Fakültesi Dergisi 7(1), 39-49.

Demir, O. (2014).Yem Sektörünün, Su ürünleri yetiştiriciliğinde sorunlarının çözümünde yapabilecekleri. Tarım Türk Dergisi, Say1 49(9), 58-63

Demir, O., \& Sarıöz, S. (2016). Development of a feeding program for early larval stage of goldfish (Carassius auratus). Turk. J. Fish. Aquat. Sci. 16,321-326.

Deveciyan, K. 2006. Türkiye'de Balık ve Balıkçılık. Aras Yayıncılık (II. Baskı), İstanbul, 574s.

FAO, (1985). Mass production of eggs and early fry. Part 1. Common carp. Isbn 92-5-102301-8, P44, Rome.

FAO, (2014). The State of World Fisheries and Aquaculture, Food And Agriculture Organization Of The United Nations, Rome,

FAO, (2016). The State of World Fisheries and Aquaculture, Food And Agriculture Organization Of The United Nations, Rome.

Farkas, A., Salanki, J., \& Specziar, A. (2003). Age- and size-specific patterns of heavy metals in the organs of freshwater fish Abramis brama L. Populating a low-contaminated site. Water Research 37, 959-964.

Fricke, R., Bilecenoğlu, M., \& Sari, H. M. (2007). Annotated checklist of fish and lamprey species (Gnathostomata and Petromyzontomorphi) of Turkey, including a Red List of threatened and declining species Stuttgarter Beiträge zur Naturkunde Serie A (Biologie) Herausgeber: Staatliches Museum für Naturkunde, Rosenstein 1, D-70191 Stuttgart Stuttgarter Beitr. Naturk. Ser. A Nr. 706169 S., 3 Abb., 8 Tab. Stuttgart, 10. IV.

Geldiay, R., \& Balık, S. (1996). Türkiye Tatlısu Balıkları. II. Baskı. Ege Üniv. Su Ür. Fak. Yay. No:46, Ders Kitabı Dizini No: 16. Ege Üniv. Basımevi, Bornova-İzmir, $532 \mathrm{~s}$.

Güner, Y., Güleç, F., İkiz, M., \& Kayac1, A. (2014). General view to Turkish carp (C. carpio) Production. Türk Bilimsel Derlemeler Dergisi 7 (2), 66-69.

Jeuthe,H., Brännäs, E., \& Nilsson, J. (2013). Effects of egg size, maternal age and temperature on egg, viability of farmed Arctic charr. Aquaculture, 408(409), 70-77.

Karakassis I., Papageorgiou, N., Kalantzi, I., Sevastou, K. \& Koutsikopoulos, C. (2013). Adaptation of fish farming production to the environmental characteristics of the receiving marine ecosystems: A proxy to carrying capacity I. Aquaculture, 408(409), 184-190.

Keskin, M.E., Taylan, D. ve Aslanbaş, T. (2015). An investigation of water potential of Lake Eğirdir, Turkey. Procedia Earth and Planetary Sciences. 15, 244-248.

Kır, İ., Erdoğan, M., \& Engin, M.S. (2013). Determination of nitrite, nitrate, phosphate and fluoride quantities in water and sediment of Eğirdir Lake, Turkey. Süleyman Demirel Üniversitesi Fen Bilimleri Enstitüsü Dergisi 19(2), 129-132. 
Kolkovski. S. (2001). Digestive enzymes in fish larvae and juveniles-implications and applications to formulated diets. Aquaculture 200, 181-201.

Küçük, F. (2006). Türkiye'deki bazı endemik içsu balıklarının dünya doğayı koruma birliği (IUCN) ölçütlerine göre değerlendirilmesi. I.Ulusal Balıklandırma ve Rezervuar Yönetimi Seтроzуити, 7-9 Şubat 2006, Antalya.

Küçük, F., Turna, İ., İ., \& Demir, O. (2007) Capoeta pestai (Pietschmann, 1933) (Pisces: Cyprinidae)'nin yayılış alanı ve taksonomik özellikleri. Süleyman Demirel Üniversitesi, Fen Bilimleri Enstitüsü Dergisi,11(1),18-25.

Küçük, F., Turan, D., Şahin, C., \& Gülle, İ. (2009). Capoeta mauricii n. sp., a new species of cyprinid fish from Lake Beysehir, Turkey (Osteichthyes: Cyprinidae). Zoology in the Middle East, 47, 71-82.

Küçük, F., \& Gülle, İ. (2015). Beyşehir Siraz balığı (Capoeta mauricii)'nın yayılış alanı, korunması ve geliştirilmesine yönelik yaklaşımlar. II. Balıklandırma ve Rezarvuar Yönetimi. 20-22 Mayıs 2015, Eğirdir.

Liao, I. C., Su, H. M., \& Chang, E.Y. (2001). Techniques in finfish larviculture in Taiwan, Aquaculture 200, 1-3

Özcan, G., \& Turan C. (2009). Threatened fishes of the world: Capoeta pestai (Pietschmann, 1933) (Cyprinidae), Environ. Biol. Fish. 84: 359-360.

Pietschmann, V. (1933). Drei neue fischarten (Cyprinidae) aus Kleinasien. Anz. Akad. Wiss., Mat. Nat. KL., Tome 70, 21-23.

Şener, Ş., Davraz, A., \& Karagüzel, R. (2013). Evaluating the anthropogenic and geologic impacts on water quality of the Eğirdir Lake, Turkey, Environ Earth Sci 70,2527-2544.

Turan, D., Kottelat, M., Kırankaya, Ş. G., \& Engin, S. (2006). Capoeta ekmekciae, A new species of cyprinid fish from northeastern Anatolia (Teleostei: Cyprinidae). Ichthyol. Explor. Freshwaters, 17(2), 147-156s.

TÜIK, (2016). Türkiye İstatistik Kurumu, Haber bülteni. Su Ürünleri, 2015. Sayı 21720, 23 Haziran 2016.

Yağc1, M. A., \& Yağc1, A. (2016). Dünden Bugüne Eğirdir Gölü Üzerine Yapılan Araştırmalar. Ayrıntı Dergisi, 4(37).

Zeybek, M., Kalyoncu, H., \& Ertan, Ö.O. (2012). The determination of trophic status in Kovada channel that connects lake Eğirdir and lake Kovada, and in the region of the lakes adjacent to the channel. Ege J Fish Aqua Sci 29(3), 137-141. 